Original Article

\title{
Transition from the French-language to the Exclusively English-language Journal Dedicated to Oral and Maxillofacial Surgery: The Transition`s Impact on Journal`s Growth, Internationalization, and Academic Career ${ }^{*}$
}

\author{
Laurent Ganry,", Oleksii O. Tymofieiev², Evangelos G. Kilipiris³, Zinaida Y. Zhehulorych", \\ Oksana D. Fesenko ${ }^{5}$, and levgen I. Fesenk $0^{6,{ }^{*}}$ \\ ${ }_{1}$ Department of Maxillo-facial, Plastic, Reconstructive and Aesthetic Surgery, Henri-Mondor Hospital, Créteil, France (MD, Assis \\ Prof) \\ ${ }^{2} \mathrm{Head}$, Department of Maxillofacial Surgery, Stomatology Institute, Shupyk National Medical Academy of Postgraduate \\ Education, Kyiv, Ukraine (ScD, Prof) \\ ${ }_{3}^{3}$ PGY4, Oral and Maxillofacial Surgery Residency Program, Comenius University, Faculty of Medicine, Bratislava, Slovak Republic. \\ ${ }^{4}$ Assoc Prof, Department of Dentistry, Institute of Postgraduate Education, Bogomolets National Medical University, Kyiv, \\ ${ }^{4}$ Assoc Prof, Department of
Ukraine ( $S c D$, Assoc Prof) \\ Ukraine (ScD, Assoc Prof)
${ }^{5}$ Language Editor, Kyiv Ivan Bohun Military Lyceum, Kyiv, Ukraine \\ ${ }^{6}$ Department of Oral and Maxillofacial Surgery, Private Higher Educational Establishment "Kyiv Medical University”, Kyiv, \\ Ukraine (PhD, Assis Prof)
}

\author{
ABOUT ARTICLE \\ Article history: \\ Paper received 05 January 2019 \\ Accepted 15 January 2019 \\ Available online 31 January 2019 \\ Keywords: \\ Language transition \\ French language \\ English language \\ OMS residency
}

\begin{abstract}
S UMMARY
Journal of Stomatology, Oral and Maxillofacial Surgery is a bimonthly peer-reviewed French publication which exists since 1874 [3]. The purposes of this paper are: 1) to analyze the publication history of the core French journal from its foundation in 1894 till nowadays, 2) to study a transition period of changing the Journal's language from French to English, 3) to understand the arguments for the language transition, and 4) to analyze the immediate positive results of the transition in a 2-year follow-up period.
\end{abstract}

(C) 2019 OMF Publishing, LLC. This is an open access article under the CC BY licence (http://creativecommons.org/licenses/by-nc/4.0/).

\begin{abstract}
There are about 275 million French speakers around the globe [1]. And the population of France is approximately 67.2 million people and it continues to grow [2]. The core French journal dedicated to oral and maxillofacial surgery (OMS) is an English-language publication - Journal of Stomatology, Oral and Maxillofacial Surgery (JSOMS)
\end{abstract}

\footnotetext{
* This manuscript has not been presented

* Corresponding author. Department of Maxillo-facial, Plastic, Reconstructive and Aesthetic Surgery, Henri-Mondor Hospital, 51, avenue du Maréchal-de-Lattre-deTassigny, 94010 Créteil, France

Tel.: +33627880651.

E-mail address: laurentganry@hotmail.fr (Laurent Ganry)

E-mails of the co-authors:

tymofeev@gmail.com (Oleksii O.Tymofieiev)

varonos@live.co.uk (Evangelos G. Kilipiris)

zhegulovih@gmail.com (Zinaida Y. Zhehulovych)

fesenko.oksana@ukr.net (Oksana D. Fesenko)

i.i.fesenko@dtjournal.org (levgen I. Fesenko)

http://dx.doi.org/10.23999/j.dtomp.2019.1.5.
}

which exists since 1874 [3]. JSOMS is a bimonthly peerreview publication and official publication of the:

1. French Society of Stomatology Maxillofacial Surgery and Oral Surgery (Société Française de Stomatologie Chirurgie Maxillo-Faciale et de Chirurgie Orale SFSCMFCO).

2. Swiss Society of Oral and Maxillofacial Surgery (Société Suisse de Chirurgie Orale et Maxillo-Faciale - SSOMFS/SSCOMF/SGMKG).

Also, the Journal is affiliated with the Belgian, the Moroccan, Romanian and Tunisian Societies. So what was the historical and lingual way of OMS Journal of one of the most populated and economically developed European country?

The purposes of this paper are: 1) to analyze the publication history of the core French journal from its 
foundation in 1894 till nowadays, 2) to study a transition period of changing the Journal's language from French to English, 3) to understand the arguments of editorial team for the language transition, and 4) to analyze the immediate positive results of the transition in a 2 -year follow-up period.

\section{Presentation of the Journal}

\section{REVUE MENSUELLE DE STOMATOLOGIE}

According to Editorial of Leger (2016), Journal was launched by Eugene Magitot in 1874 [3]. Issues for 1894-1898 had a title: Revue mensuelle de stomatologie (Table 1) [4].

\section{LA REVUE DE STOMATOLOGIE}

From 1898 to 1968 the Journal was published with a title La revue de stomatologie [5]. Journal (Fig 1) was an official organ of Société de Stomatologie de France from 1948 to 1954, and of the Société de Stomatologie et de Chirurgie Maxillo-faciale de France from 1954 to 1968.

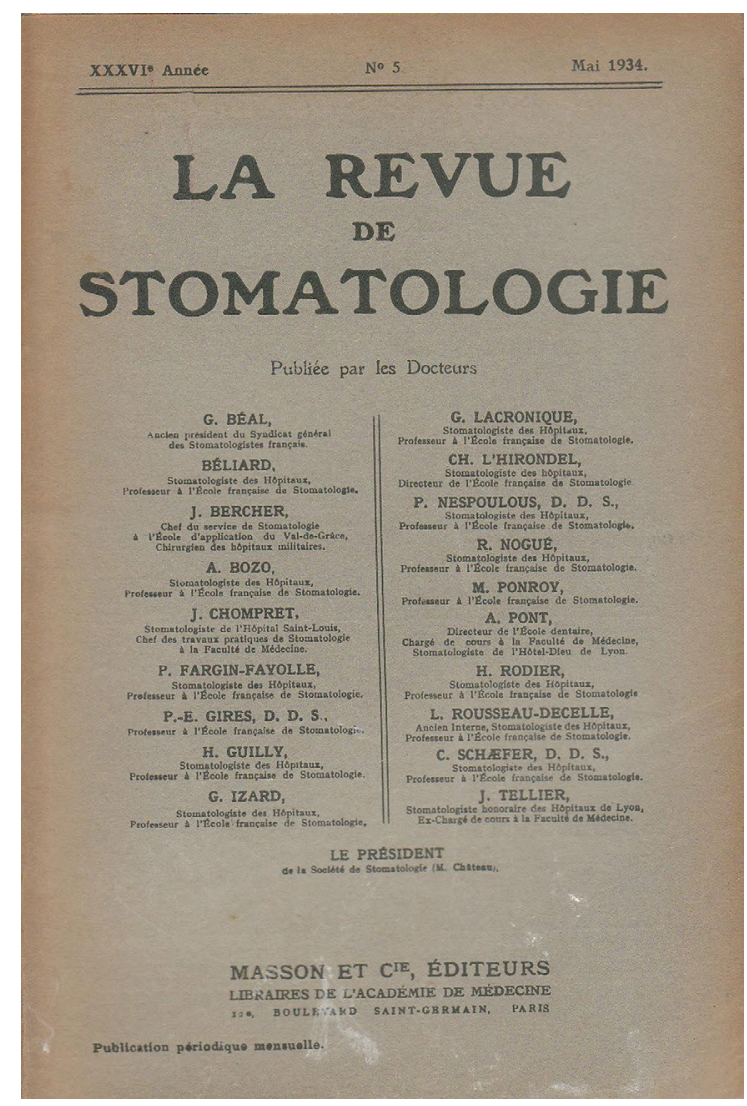

FIGURE 1. Editorial Board page of the monthly publication - La revue de stomatologie. Issue 5, 1934

\section{REVUE DE STOMATOLOGIE ET DE CHIRURGIE MAXILLO-FACIALE}

From 1968 the publication La revue de stomatologie was renamed into Revue de Stomatologie et de Chirurgie Maxillo-faciale (Fig 2B) (Journal's title from 1968 to 2012) [6].

In 2012, the editorial team of Revue de Stomatologie et de Chirurgie Maxillo-faciale noted in the Editorial next important points [7]:

1. Despite of being a French Journal, it publishes articles in the English language and for a long time (from 2009).

2. Using online submission, articles from many French- speaking countries (Switzerland, Belgium, Tunisia, Morocco, Algeria, Africa, Canada) are submitted.

3. Impressed that authors from non-French speaking countries (China, Germany, Italy, Brazil, Austria, etc.) are also beginning to submit.

4. Increase in the number of articles published in English will whine the supporters of the "all French", but should allow increasing the Impact Factor of the Journal.

\section{REVUE DE STOMATOLOGIE ET DE CHIRURGIE MAXILLO-FACIALE AND IMPLANTODONTIE}

Other French Journal, Implantodontie (Fig 2A), was incorporated into a Journal - Revue de Stomatologie et de 
Chirurgie Maxillo-faciale at the end of 2005 (Fig 2) after 14 years of publishing (from 1991). And from 2006 Revue de Stomatologie et de Chirurgie Maxillo-faciale received a word 'Implantologie' (Fig 3) below the title as indication of the incorporation.

According to Cantaloube and Bettega (2006), the decision of editorial office about incorporation of the Implantodontie based on several reasons [8]. The key of which were:

1. After the incorporation, the Journal and its content will become more competitive.

2. The Journal Revue de Stomatologie et de Chirurgie Maxillo-faciale has already expanded its readership to the entire Francophone community.
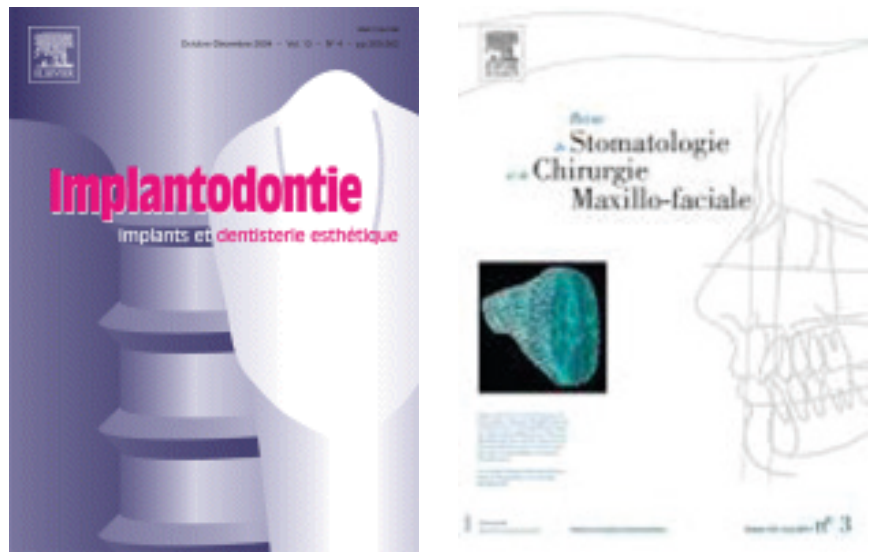

FIGURE 2. Cover of the Implantodontie (A) before incorporation in 2005 into a Journal - Revue de Stomatologie et de Chirurgie Maxillo-faciale (B).

\section{REVUE DE STOMATOLOGIE ET DE CHIRURGIE MAXILLO-FACIALE ET DE CHIRURGIE ORALE}

From 2013 to the last Issue of 2016, the Journal had a title Revue de Stomatologie, de Chirurgie Maxillo-faciale et de Chirurgie Orale (Fig 4).

In 2011, the French qualification in Oral Surgery was created. This major change in the French healthcare system invigorates the need for a major overhaul of its institutions. Therefore, the French Maxillofacial Society as the National Scientific Maxillofacial Journal changes their names. In France, Oral Surgery's purpose was to replace Stomatology to balance the lack of equivalence within the European Union as Stomatology doesn't exist in the vast majority of European countries as a specialty of the curriculum in medicine. Oral surgery diploma can be obtained in France from dental student (5th grade) as medical students (6th grade). But an oral surgeon will not be able to obtain the qualification in Oral and Maxillofacial surgery, and therefore will not be able to have a practice outside of the oral cavity, as it is a specialty from the medical field with a complete different training program, which is equivalent to any other medical surgical specialty in France.

Motivation criteria for transition from French to exclusively English-language Journal were precisely described by Leger in 2016 [3]:

1. Transition will allow the publication of works by French teams engaged in international competition to be better disseminated (more articles, appearing quickly).

2. The publication in English is a continuation of the stated ambition of a journal serving its discipline and wishing to make a place for itself in France and in the world.

3. In terms of visibility and dissemination, the language change will allow, through the indexing services (including PubMed/Medline), the immediate identification of items in JSOMS, being in English.

4. On the content platforms (e.g., ScienceDirect) and via the social networks, such as the hosting and sharing sites (such as Mendeley), more items will be viewed and downloaded.

\section{JOURNAL OF STOMATOLOGY, ORAL AND MAXILLOFACIAL SURGERY}

Editor in Chief of the Journal Prof. Christophe Meyer in Editorial "A new year, a new journal, new ambitions" (2017) reported that: 1) Journal received new English title (Fig 5), 2) English has become their official and exclusive language of publication and also noticed next statements [9]:

1. Promotion of francophonie does not only mean publishing in French language but also consists in a diffusion of the work French surgical teams produce as large as possible.

2. The transition to English will help the medical students to validate more easily the prerequisites needed for an academic carreer in France.

3. One of these academic prerequisites, according to Meyer, being the publication of a certain number of publications precisely in international indexed English-language journals.

4. This not just a shift to English, this is a shift to English 
as the universal scientific language.

5. Strong internationalization of the journal is noted. Since September 2016, manuscripts coming more and more from non-French speaking countries.

6. An $18 \%$ increase of submissions in the last 4 months of 2016 compared to 2015 was noted. That fact enables the editorial board to select the best manuscripts to be published.

All these efforts (changing the title, transition to Englishlanguage Journal) of the editorial team and a publisher were the price to pay for an increase the Journal's Impact Factor and to establish a new growth for the publication [9].

Generally, with a new title in 2017 only three first issues have a small quantity of French-language articles (Table 2). And officially starting from 4th Issue (Volume
$118,2017)$ the Journal published only English-language content (Table 2).

In 2018 Meyer noted, that transition from a Frenchlanguage Journal towards a fully English-language journal brought a lot of positive results [10]:

1. Ensured the optimal worldwide dissemination of our authors' works.

2. After the transition the Editorial Board have recorded a sharp increase in the number of submissions of about $60 \%$.

3. Articles have come from over 20 countries.

4. The quality of the papers has improved markedly.

5. Article downloads have risen significantly.

6. These results strongly suggest an increase in the Impact Factor (IF) of the JSMOS over the next few years.

TABLE 1. Historical Changes of the Journal 's Title and a Language of Publication From 1894, the Year of Foundation, to Nowadays, 2019.

\begin{tabular}{|c|c|l|c|}
\hline$\#$ & Years & \multicolumn{1}{|c|}{ Evolution of the Journal 's Title } & Journal 's Language \\
\hline 1 & $1894-1898$ & Revue mensuelle de stomatologie & French \\
\hline 2 & $1898-1968$ & Revue de stomatology (La revue de stomatology) & French \\
\hline 3 & $1968-2013$ & Revue de Stomatologie et de Chirurgie Maxillo-faciale & French \\
\hline 4 & $2013-2016$ & Revue de Stomatologie, de Chirurgie Maxillo-faciale et de Chirurgie Orale & French and English \\
\hline 5 & $2017-$ now & Journal of Stomatology, Oral and Maxillofacial Surgery & English \\
\hline
\end{tabular}

TABLE 2. Period 2009-2017: 8-Year Transition From French to English-Language Articles in the Revue de Stomatologie et de Chirurgie Maxillo-faciale (Journal 's Title From 1968 to 2012), Revue de Stomatologie, de Chirurgie Maxillo-Faciale et de Chirurgie Orale (Journal 's Title From 2013 to 2016), and Journal of Stomatology, Oral and Maxillofacial Surgery (Journal 's Title From 2017-Now) [6]. (Table 2 continued on next page)

\begin{tabular}{|c|c|c|c|c|}
\hline & $\begin{array}{l}\text { Total Amount of } \\
\text { Articles in Issue }\end{array}$ & Articles in French & Articles in English & $\begin{array}{l}\text { Bilingual Articles } \\
\text { (Simultaneously in French and English) }\end{array}$ \\
\hline \multicolumn{5}{|c|}{$\begin{array}{l}\text { Revue de Stomatologie et de Chirurgie Maxillo-faciale } \\
\text { (Journal's title from } 1968 \text { to 2013) }\end{array}$} \\
\hline Volume 110, issue 1, 2009 & 15 & 15 & - & - \\
\hline Volume 110, issue 2, 2009 & 17 & 17 & - & - \\
\hline Volume 110, issue 3, 2009 & 13 & 13 & - & - \\
\hline Volume 110, issue 4, 2009 & 16 & 16 & - & - \\
\hline Volume 110, issue 5, 2009 & 16 & 16 & - & - \\
\hline Volume 110, issue 6, 2009 & 18 & 18 & - & - \\
\hline Volume 111, issue 1, 2010 & 15 & 15 & - & - \\
\hline Volume 111, issue 2, 2010 & 19 & 16 & 3 & - \\
\hline Volume 111, issue 3, 2010 & 19 & 18 & 1 & - \\
\hline Volume 111, issue 4, 2010 & 17 & 15 & 2 & - \\
\hline Volume 111 , issue 5-6, 2010 & 20 & 20 & - & - \\
\hline Volume 112, issue 1, 2011 & 11 & 11 & - & - \\
\hline Volume 112, issue 2, 2011 & 16 & 15 & 1 & - \\
\hline Volume 112, issue 3, 2011 & 19 & 18 & 1 & - \\
\hline Volume 112, issue 4, 2011 & 10 & 10 & - & - \\
\hline Volume 112, issue 5, 2011 & 16 & 16 & - & - \\
\hline Volume 112, issue 6, 2011 & 16 & 15 & 1 & - \\
\hline
\end{tabular}


TABLE 2 (cont'd). Period 2009-2017: 8-Year Transition From French to English-Language Articles in the Revue de Stomatologie et de Chirurgie Maxillo-faciale (Journal 's Title From 1968 to 2012), Revue de Stomatologie, de Chirurgie Maxillo-Faciale et de Chirurgie Orale (Journal 's Title From 2013 to 2016), and Journal of Stomatology, Oral and Maxillofacial Surgery (Journal 's Title From 2017-Now) [6]. (Table 2 continued on next page)

\begin{tabular}{|c|c|c|c|c|}
\hline & $\begin{array}{l}\text { Total Amount of } \\
\text { Articles in Issue }\end{array}$ & Articles in French & Articles in English & $\begin{array}{l}\text { Bilingual Articles } \\
\text { (Simultaneously in French and English) }\end{array}$ \\
\hline Volume 113, issue 1, 2012 & 20 & 20 & - & - \\
\hline Volume 113, issue 2, 2012 & 16 & 16 & - & - \\
\hline Volume 113, issue 3, 2012 & 14 & 13 & 1 & - \\
\hline Volume 113, issue 4, 2012 & 15 & 15 & - & - \\
\hline Volume 113, issue 5, 2012 & 17 & 16 & 1 & - \\
\hline Volume 113, issue 6, 2012 & 15 & 14 & 1 & - \\
\hline \multicolumn{5}{|c|}{$\begin{array}{c}\text { Revue de Stomatologie, de Chirurgie Maxillo-faciale et de Chirurgie Orale } \\
\text { (Journal's title from } 2013 \text { till the end of 2016) }\end{array}$} \\
\hline Volume 114, issue 1, 2013 & 13 & 11 & 2 & - \\
\hline Volume 114, issue 2, 2013 & 17 & 16 & 1 & - \\
\hline Volume 114, issue 3, 2013 & 20 & 16 & 4 & - \\
\hline Volume 114, issue 4, 2013 & 12 & 12 & - & - \\
\hline Volume 114, issue 5, 2013 & 13 & 9 & 4 & - \\
\hline Volume 114, issue 6, 2013 & 11 & 11 & - & - \\
\hline Volume 115, issue 1, 2014 & 19 & 15 & 4 & - \\
\hline Volume 115, issue 2, 2014 & 19 & 17 & 2 & - \\
\hline Volume 115, issue 3, 2014 & 13 & 13 & - & - \\
\hline Volume 115, issue 4, 2014 & 10 & 9 & 1 & - \\
\hline Volume 115, issue 5, 2014 & 17 & 15 & 2 & - \\
\hline Volume 115, issue 6, 2014 & 16 & 15 & 1 & - \\
\hline Volume 116, issue 1, 2015 & 12 & 10 & 2 & - \\
\hline Volume 116, issue 2, 2015 & 16 & 16 & - & - \\
\hline Volume 116, issue 3, 2015 & 13 & 13 & - & - \\
\hline Volume 116, issue 4, 2015 & 13 & 12 & 1 & - \\
\hline Volume 116, issue 5, 2015 & 10 & 8 & 2 & - \\
\hline Volume 116, issue 6, 2015 & 14 & 11 & 3 & - \\
\hline Volume 117 , issue 1,2016 & 13 & 11 & 2 & - \\
\hline Volume 117, issue 2, 2016 & 15 & 13 & 2 & - \\
\hline Volume 117, issue 3, 2016 & 19 & 16 & 3 & - \\
\hline Volume 117, issue 4, 2016 & 19 & 19 & - & - \\
\hline Volume 117, issue 5, 2016 & 13 & 6 & 6 & 1 (Editorial) \\
\hline Volume 117, issue 6, 2016 & 18 & 17 & 1 & - \\
\hline \multicolumn{5}{|c|}{$\begin{array}{c}\text { Journal of Stomatology, Oral and Maxillofacial Surgery } \\
\text { (Journal's title from } 2017 \text { till now) }\end{array}$} \\
\hline Volume 118, issue 1, 2017 & 15 & 5 & 10 & - \\
\hline Volume 118, issue 2, 2017 & 16 & 8 & 8 & - \\
\hline Volume 118, issue 3, 2017 & 14 & - & 13 & - \\
\hline Volume 118, issue 4, 2017 & 13 & - & 13 & - \\
\hline Volume 118, issue 5, 2017 & 18 & - & 18 & - \\
\hline Volume 118, issue 6, 2017 & 17 & - & 17 & - \\
\hline Volume 119, issue 1, 2018 & 22 & - & 22 & - \\
\hline Volume 119, issue 2, 2018 & 21 & - & 21 & - \\
\hline
\end{tabular}




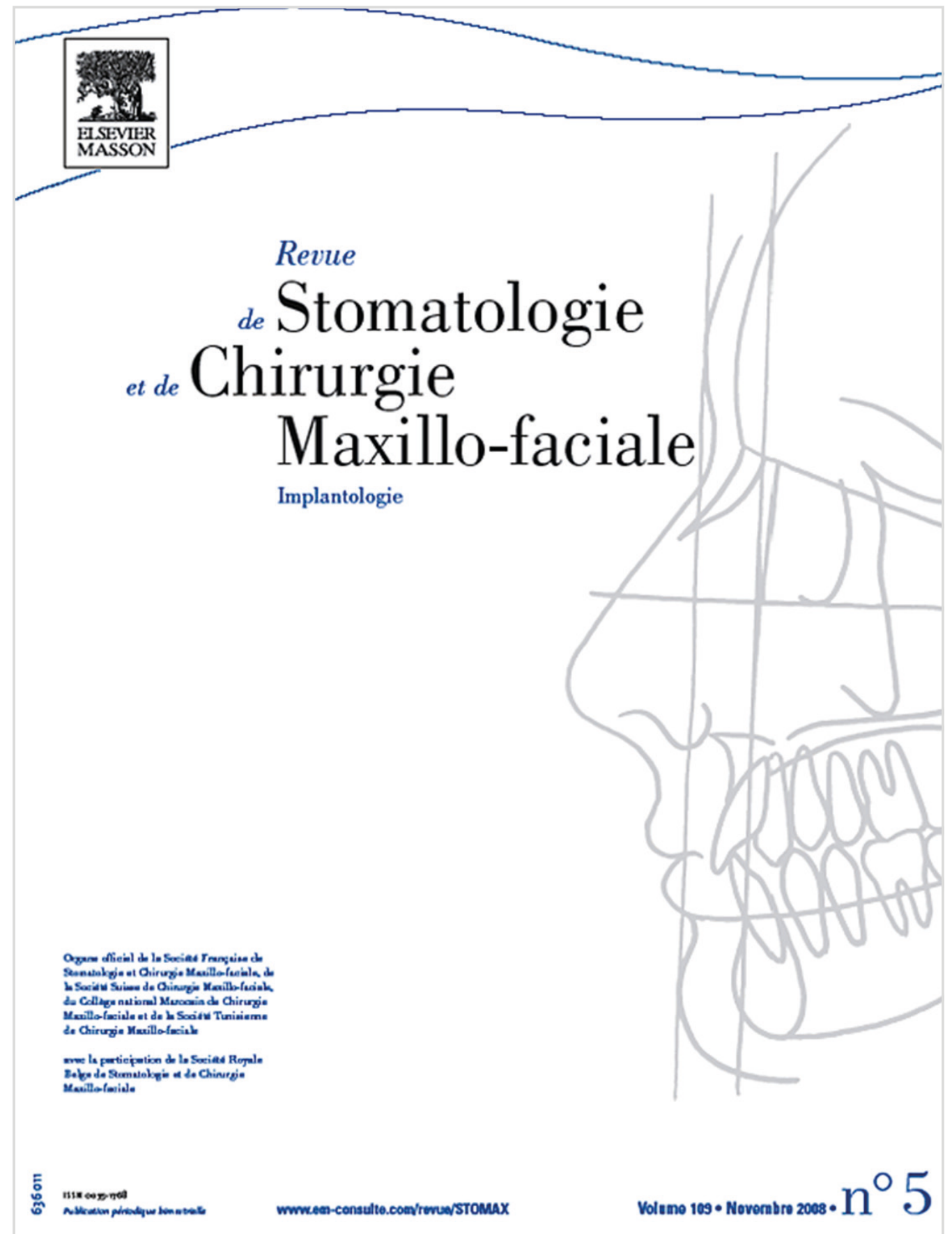

FIGURE 3. Cover of the French language Journal - Revue de Stomatologie et de Chirurgie Maxillo-faciale (Volume 109, Issue 5, November 2008) with a word Implantologie below the title what is indicated about incorporation of other French Journal, Implantodontie, with Revue de Stomatologie et de Chirurgie Maxillo-faciale. 


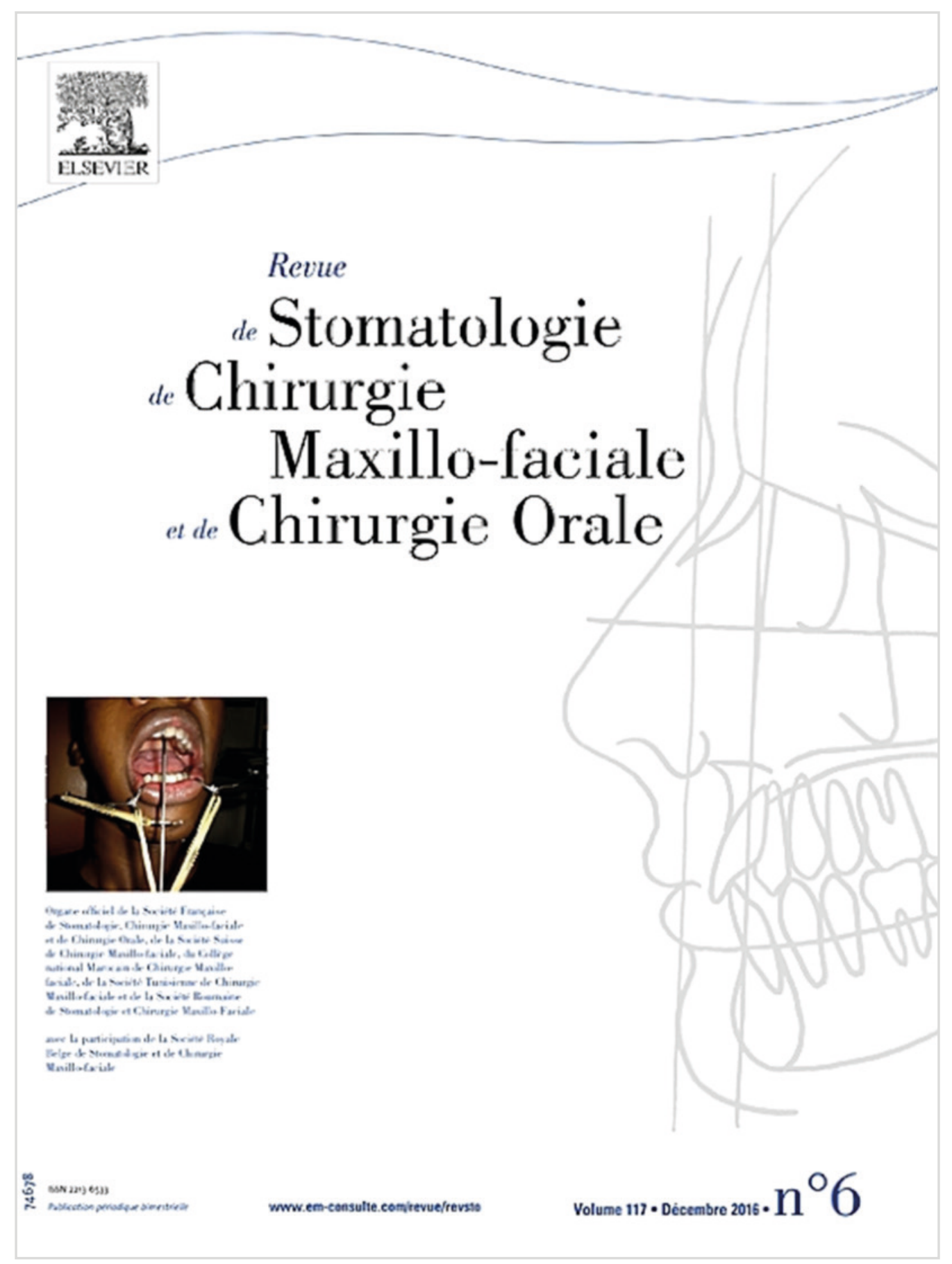

FIGURE 4. Cover of the French language Journal - Revue de Stomatologie, de Chirurgie Maxillo-faciale et de Chirurgie Orale (Volume 117, Issue 6, December 2016) at final stage of language transition into completely English version from 2017 (Journal ’s title from 2017 - Journal of Stomatology, Oral and Maxillofacial Surgery). 


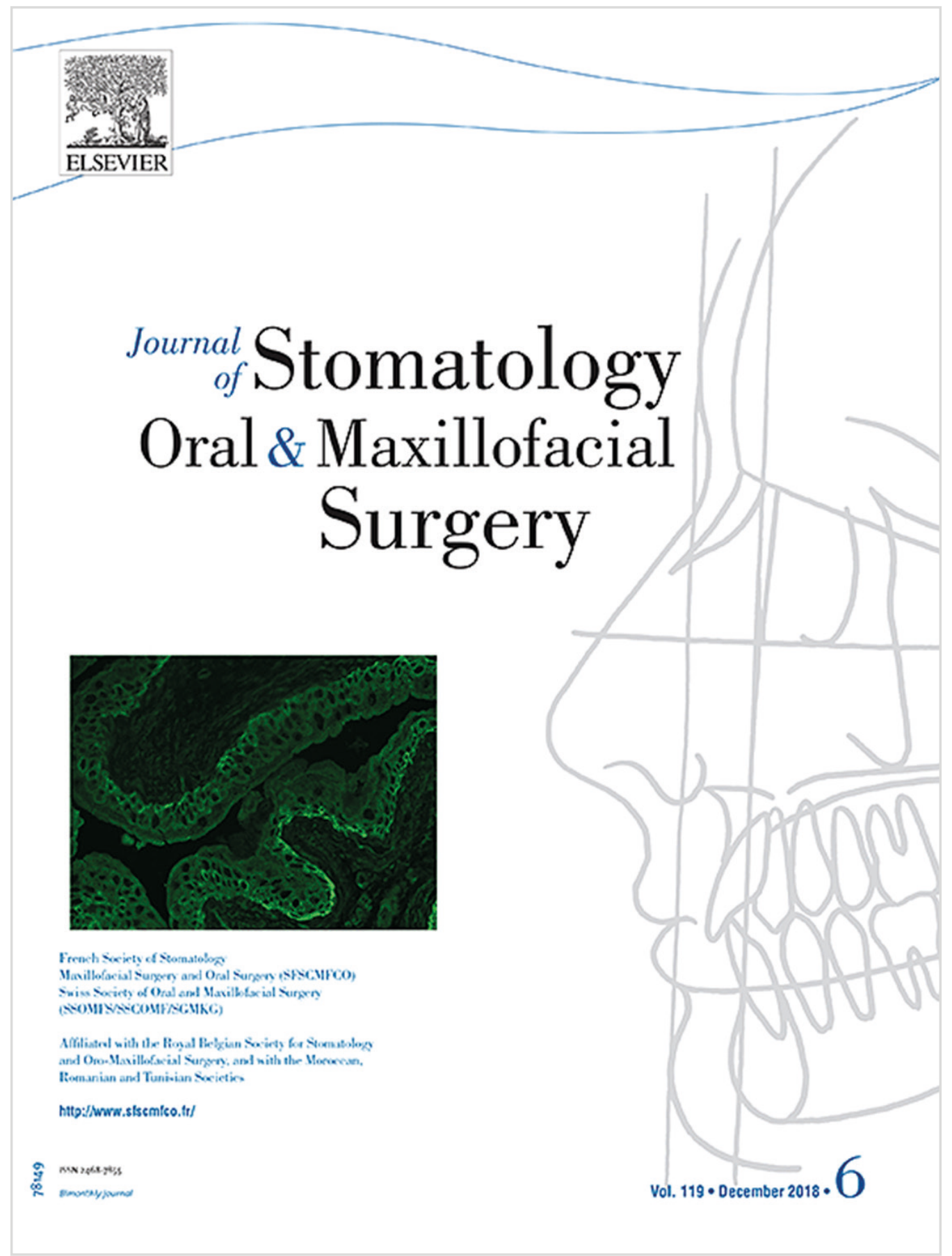

FIGURE 5. Cover of Journal of Stomatology, Oral and Maxillofacial Surgery (Volume 119, Issue 6, December 2018) after the language transition into completely English version from 2017 (Journal 's title from 2013 till the end of 2016 was Revue de Stomatologie, de Chirurgie Maxillo-faciale et de Chirurgie Orale). 


\section{Results}

According to our study of the long, majestic, and successful history of the core French Journal dedicated to oral and maxillofacial surgery we received next results:

1. During the Journal's 125-year history (from 1894) the Journal have 5 different titles (Table 1) and current title is an English-language title.

2. In 2005, another Journal, Implantodontie, dedicated to implants and dentistry was incorporated into Revue de Stomatologie et de Chirurgie Maxillofaciale [8].

3. Language transition of the Journal from French to English took place within 8 years, from 2010 to 2017.

4. The language transition of the famous French OMS Journal proved the last world tendency similar to language transition of both South Korean OMS journals in 2012 and 2014 [11, 12].

\section{Conclusions}

Disadvantages of transition from national-language journal to fully English-language journal:

1. The transition can be a painful process for the readers and authors of native language.

Advantages of transition from French-language to fully English-language journal:

1. Worldwide dissemination of our authors' works. Downloads of papers can rise significantly.

2. A sharp increase in the number of submissions of about $60 \%$ can be achieved taking into account French journal experience.

3. Increased number of submissions enables to select the cutting-edge manusrcripts to be published.

4. The transition is strongly suggesting an increase in the Impact Factor.

5. Strong internationalization of the journal would be achieved.

6. The transition to English can help in prerequisites during OMS residency training programs and academic career.

\section{Role of the Co-authors}

All authors are equally contributed to that article. All authors read and approved the final manuscript.

\section{Fundings}

No funding was received for this study.

\section{References}

1. Why French matters. Available at: https://foreignlanguages. camden.rutgers.edu/french/why-french-matters/ Access January 17, 2019.

2. What you need to know about the French population in 2018. Available at: https://www.thelocal.fr/20180116/whatyou-need-to-know-about-frances-population-in-2018 Access January 17, 2019.

3. Leger P. The Revue becomes Journal of Stomatology Oral and Maxillofacial Surgery. Rev Stomatol Chir Maxillofac Chir Orale 2016;117(5):303-5.https://doi.org/10.1016/j.revsto.2016.10.001.

4. Revue mensuelle de stomatologie. Available at: https://catalog. hathitrust.org/Record/010605263 Access January 17, 2019.

5. Revue de stomatologie. Available at: https://www.ncbi.nlm. nih.gov/nlmcatalog/201163 Access January 17, 2019.

6. Revue de stomatologie et de chirurgie maxillofaciale. Available at: https://www.ncbi.nlm.nih.gov/ nlmcatalog/0201010 Access January 17, 2019.

7. La redaction. Do you speak british or französich? (parlez-vous anglais ou français ?) [in French]. Rev Stomatol Chir Maxillofac 2012;113(1):7. https://doi.org/10.1016/j.stomax.2012.01.003.

8. Cantaloube D, Bettega G. A merging for opening up. Implatodontie 2005;14(4):153. https://doi.org/10.1016/j. implan.2006.07.001.

9. Meyer C. A new year, a new journal, new ambitions. J Stomatol Oral Maxillofac Surg 2017;118(1):1. https://doi. org/10.1016/j.jormas.2017.01.002.

10. Meyer C. Switch to English: one year after. J Stomatol Oral Maxillofac Surg 2018;119(1):1. https://doi.org/10.1016/j. jormas.2018.01.002.

11. Tymofieiev OO, Fesenko OD, Fesenko II. Transition from Korean to English language of South Korean journals both dedicated to the oral and maxillofacial surgery (OMS): the transitions' impact on OMS residency programs. J Diagn Treat Oral Maxillofac Pathol 2018;2(4):155-64. http:// dx.doi.org/10.23999/j.dtomp.2018.4.3.

12. Kwon TG. Prerequisites for international article: suggestion for our publication system. J Korean Assoc Oral Maxillofac Surg 2012;38(3):184-5. https://doi.org/10.5125/ jkaoms.2012.38.3.184 